InOedia $\quad \begin{aligned} & \text { InMedia } \\ & \text { The French Journal of Media Studies }\end{aligned}$

8.1. $\mid 2020$

Ubiquitous Visuality

\title{
Contemporary Text Experiences and Storytelling
}

\section{Cécile Beaufils}

\section{(2) OpenEdition \\ Journals}

Electronic version

URL: http://journals.openedition.org/inmedia/2047

DOI: 10.4000/inmedia.2047

ISSN: 2259-4728

\section{Publisher}

Center for Research on the English-Speaking World (CREW)

\section{Electronic reference}

Cécile Beaufils, "Contemporary Text Experiences and Storytelling", InMedia [Online], 8.1. | 2020, Online since 15 December 2020, connection on 26 January 2021. URL: http://journals.openedition.org/ inmedia/2047; DOI: https://doi.org/10.4000/inmedia.2047

This text was automatically generated on 26 January 2021.

(c) InMedia 


\title{
Contemporary Text Experiences and Storytelling
}

\author{
Cécile Beaufils
}

1 In 2014, British writer Will Self gave a lecture in Oxford in which he declared the novel dead:

The form should have been laid to rest at about the time of Finnegans Wake, but in fact it has continued to stalk the corridors of our minds for a further three-quarters of a century. Many fine novels have been written during this period, but I would contend that these were, taking the long view, zombie novels, instances of an undead art form that yet wouldn't lie down. ${ }^{1}$

2 This declaration is meant to be provocative and yet, the "death of the novel" argument now seems to be defunct itself-and so is the proclamation of the end of the book in its printed format at least since the 1960s. ${ }^{2}$ Self, in a burst of rebellion against the state of novel-writing, tries to reinvigorate this stance by including the digital as the main cause of the novel turning into an outdated art form. According to the novelist, who has completed, with the publication of Phone in Spring 2017, an ambitious trilogy explicitly designed not to be easily read and which the author has compared to a modernist enterprise, this demise of the form is mostly caused by the advent of a new publication format, meaning the end of the publication in the form of the codex (a bound printed volume). In his lecture, he explains that these changes in the material form of the book influence the way we apprehend texts: "the advent of digital media is not simply destructive of the codex, but of the Gutenberg mind itself." ${ }^{3}$ The nowclassic, if debated expression "Gutenberg mind" is derived from Marshall McLuhan's "interiorization of technology"4 and shows how Self follows McLuhan's position when he explained that the technological revolution that was the printing press also changed the way we think. In McLuhan's terminology, people who learn how to read in a linear fashion possess such a "Gutenberg mind." of course, such an assertion is to be taken with a grain of salt, but it has nevertheless proved influential, as evidenced by Self's declaration. The novelist's conclusion, in this respect, is that the "serious novel" as he calls it, as an antiquated form, will still exist but will be confined to a smaller audience: "it will be an art form on a par with easel painting or classical music: confined to a 
defined social and demographic group, requiring a degree of subsidy, a subject for historical scholarship rather than public discourse."

Self developed his argument more recently, in a conference he gave during the Scottish Book Week in November 2016. ${ }^{6}$ In this talk, he questions once again the impact of new technologies on our brain. He underlines in particular the fact that storytelling is, in his opinion, intrinsically connected to spatial memories: one tells stories to find one's way. Such a position is striking since it is defended by an author who explores modernist concerns of thought and writing in his most recent works (Umbrella, Shark and Phone)- in the author's words, "the connections between technological change, warfare and human psychopathology." In these novels, Self questions the existence of the reading subject and the conditions of our cognition of the world-in a purely theoretical manner, outside of the realm of neurosciences ${ }^{8}$. What transpires in the way this established author challenges the written word (and what draws our attention to his surprising declarations) is the problematization of the notion of storytelling. Indeed, the multiplication of reading-and writing-devices implies a modification not only of our reading habits, but also of the way storytelling is achieved in the realm of fiction. Literature has evolved in a radical manner in the digital age, and the question at stake here is to know how it has tackled issues of reader engagement (how readers connect to what they read) and hybridization (texts existing on several platforms). Self's return to a much older stance towards the novel, and the impact of such an author, may lead us to question the extremely varied attempts to consider storytelling and its connection to the book as object in contemporary literature.

The distinction between print and digital in the literary field can be traced to the appearance of electronic literature, but as N. Katherine Hayles points out, the two fields are not necessarily opposed. Both are connected to the digital and are therefore hybrid. The difference resides in the material medium which the reader is meant to access: "Electronic literature, generally considered to exclude print literature that has been digitized, is by contrast "digital born," a first-generation digital object created on a computer and (usually) meant to be read on a computer."

Electronic literature ${ }^{10}$ has been part of the avant-garde since the digital turn and has progressively become more visible to a wider readership than before, if only because of the development of new, cheaper portable hardware (e-readers, tablets, larger smartphones). Its influence on print cannot be denied, as printed books occasionally try to imitate digital publications, or on the contrary, highlight all the ways in which they diverge from electronic literature. Recent examples frequently include an intermedial approach, especially since Mark Z. Danielewski's now classic example of ergodic literature House of Leaves. Such texts play not only with typography but also with intermediality, often choosing to insert elements from the digital sphere onto the page, transposing one medium to another. For instance, Night Film: a Novel (2013) by Marisha Pessl builds the core mystery of the novel thanks to multiple false screen captures of blogs and magazine or newspaper articles-thus giving the illusion of an electronic text when the reader is presented with the reproduction of an electronic text, thus a remediation ${ }^{11}$. Specific extra material also features in the digital edition of the novel, which starts with a set of instructions:

DEAR READER, If you want to continue the Night Film experience, interactive touch points buried throughout the text will unlock extra content on your smartphone or tablet. These hidden Easter eggs include new images and audio. If you have a device with a rear-facing camera (connected to WiFi or a cellular network), please follow 
these steps to access the bonus content: Visit NightFilmDecoder.com to learn how to download the free app. Install the Night Film Decoder app on your device. Search for the bird image below in select illustrations throughout Night Film. When you see it, launch the app on your device and scan the illustration with the camera until a Play button appears on the screen. Hint: Not every one hides a secret. ${ }^{12}$

In the prologue to the novel, the protagonist learns of the death of a notoriously reclusive film director's daughter. Several screen captures are included; they are seemingly taken from existing sources, newspapers (The New York Times and TIME) in particular. Later on in the novel, social media platforms are added. In this first series of screen captures, the reader/viewer follows the reading path of the protagonist though a false 18-page TIME article entitled "The Last Enigma,"13. On each page, a photograph and text appear, and the URL is visible. The aforementioned "bird image" appears twice (once at the bottom of the text, once as the main image of the web page), providing the reader with extra content -sound bites, video snippets, text. The illusion that we are watching a real screen capture is complete, with the graphic chart of recognizable web browsers, the presence of believable URLs and, at the bottom of the page, links to various social media outlets usually present at the bottom of news articles for quick reposting. The reproduction of the main character's reading and investigating processes, as he is a journalist, showcases the integration of print and digital in a single work, with a novel that still fits within the parameters of the thriller and the crime novel.

7 Such narrative choices on the part of authors (and editorial choices from publishing houses having access to cheaper printing or display techniques) confirm the proximity of these texts to what Alexander Galloway chose to call interfaces, "the point[s] of transition between different mediatic layers within any nested system." ${ }^{14}$ To create such interfaces, electronic reading devices try to emulate the physical act of turning a page, attempting to bridge the physical gap between the reading device and the material book. Other productions, referred to under the umbrella term "transmedia storytelling," ${ }^{15}$ contain both material and digital aspects. Transmedia storytelling is to be found particularly in the realm of video games and in the film industry, especially in franchises like the Harry Potter series or The Lord of The Rings, ${ }^{16}$ and in earlier cases, 1980s adaptations of Star Wars into video games, or popular roleplaying games like Dungeons and Dragons, since some storylines were adapted into novels and video games. Henry Jenkins defines transmedia storytelling as "the art of world-making." ${ }^{17}$ This process, which Hayles compares to a "Möbius loop"18 (a one-sided surface modeled as an unending loop) of retroactive influence, is crucial in understanding issues inherent to recent forms of transmedia storytelling, ${ }^{19}$ and how immersion and interactivity ${ }^{20}$ are inherent to these developments. However, the reconfigurations of the publishing world have brought about changes in the way storytelling is approached. We will therefore essentially focus on the way a few contemporary authors like Hari Kunzru, Neil Gaiman and Marisha Pessl and publishing houses like Penguin or Visual Editions deal with the ongoing modifications of storytelling.

\section{Fragmented forms and experience}

Self, in his lectures, targets a change in reading practices, which he says is caused by the multiplication of reading devices (computers, tablets, smartphones) and the rising popularity of the short form. And indeed, some forms of electronic literature shaped by 
their publication outlet are based on a fragmented narration which the reader can access in snippets. ${ }^{21}$ Such a way of telling stories enables the authors to modify how they capture the reader's attention, which is a crucial part of the creative process (and also central to the immersive nature of transmedia storytelling ${ }^{22}$ ).

9 Attention has become the lynchpin of contemporary storytelling in all its forms, and subject to much debate. The question of the reader's (or the spectator's) attention is already crucial in the age of modernity, both regarding economic and artistic concerns. One of the first occurrences of the question can be found in Walter Benjamin's essay "The Work of Art in the Age of Mechanical Reproduction,"23 thus foregrounding the importance of the material conditions of production, and artistic creation. Benjamin tackles the issue of how works of art may be paid attention to or not by observing a diminished capacity of focus in the modern mass film audience, which he calls distraction: "[a] reception in a state of distraction, which is increasing noticeably in all fields of art and is symptomatic of profound changes in apperception, finds in the film its true means of exercise." ${ }^{24}$ The modern audience, according to him, is increasingly incapable of directing its full focus at a single given work of art; Benjamin concludes his reflection on a pessimistic declaration: "The public is an examiner, but an absentminded one." ${ }^{25}$ Modernity is therefore not only concerned with the existence of a reading subject, but also with their attentional focus, and many critics, like Will Self, have seized on these remarks to claim that the long narrative form is reaching the end of its life-span. In contemporary cultural studies, attention has surfaced as a central notion in the observation of the multiplication of media, screens, sources of distraction -which nevertheless does not signify an inability to focus. Such a perceived state of fragmentation has led Jonathan Crary to describe our lives as visual patchworks, in the context of what he calls, after Guy Debord's 1967 The Society of the Spectacle, "spectacular culture": "spectacular culture is not founded on the necessity of making a subject see, but rather on strategies in which individuals are isolated, separated, and inhabit time as disempowered." ${ }^{26}$ Attention takes on many forms, and requires a stimulation of sensory perceptions.

In such a context of challenged reading experiences, how can storytelling still occur? Some authors, like Will Self, have chosen to deliberately eschew the problem while acknowledging its existence. In Umbrella, several timeframes and spaces meet in the narrator's mind, therefore creating a collision which signals the character's inability to follow a linear narrative, a technique reminiscent of high-modernism. Such a fragmentation, in this particular case, shows the fracturing of attention when it comes to the longer narrative form, while paying homage to modernist technique. However, some authors and publishing platforms have chosen to embrace this fragmentation.

11 This experimentation has for instance taken the form of storytelling through text messages, a hybrid form specific in its combination of seriality and brevity. This publication format appeared before social media, in the 1990s in Japan, culminating in the early 2000s with extremely popular novels like the 2007 bestseller Moshimo Kimiga, by Rin. ${ }^{27}$ Although its format means it is now outdated, it has survived on more recent platforms. Digital productions are often faced with the problem of obsolescence and accessibility, and in this case, a lot of text message stories have been moved to websites -for instance, the popular fan fiction platform Wattpad features a "Cell Phone Novel Network" section. ${ }^{28}$ This translation, in the literal sense, means the texts survive, but they also lose some of their formal specificities like their original brevity. A more 
contemporary version of this format has appeared with instances like the popular iPhone application HOOKED, which lets its users write and post text message stories and more specifically suspense short stories. Users of the application are welcomed with the following enthusiastic message: "These are gripping, edge-of-your seat thrillers that will keep you reading for hours. Or, write your own story and get lots of fans! Every HOOKED story is told as a bite-sized text message conversation, as if you were reading someone else's chat history." ${ }^{29}$ Most of the stories target a young adult audience, with the use of vernacular English and text-message spelling, with recent successful young adult franchises as a frame of reference: "If you can't get enough of books like Hunger Games, Divergent, The Fault In Our Stars and Harry Potter. Or if you're a fan of fanfic, like stories about One Direction. [...] And even if you're not a big reader, but you love Snapchat, you should give HOOKED a try!" ${ }^{30}$ This relatively recent form of storytelling brings together characteristics of the serial, the radio play and the epistolary novel. Its episodic nature is pushed to an extreme, and combined with a descriptive element aiming at giving an impression of simultaneity. The characters, being in different locations, describe what they see for an absent reader, therefore following the same logic as the once-popular epistolary novel. Like the now dominant self-publishing platform Wattpad, HOOKED should be considered as one of the new modalities of both reading and writing.

Such a fragmented way of telling stories is not restricted to avant-garde authors or writers targeting a young adult audience; it has also been adopted by authors outside genre fiction. For example, Teju Cole, following Jennifer Egan's Twitter novel Black Box (2012), published a Twitter short story entitled "Hafiz" in 2014: in 31 "retweets," the author tells the story of a man found on the sidewalk, and the impact the scene has on different bystanders. Teju Cole sent the messages individually to some of his friends, who then posted the sentences; the author then "retweeted" said sentences to create a mosaic of texts, and a reconstructed narrative. The intent and effect are entirely opposed to the stories available on Hooked, since storytelling is achieved through fragmentation and recomposition and comes closer to nonlinear than linear narration, which the author called "distributed storytelling" ${ }^{31}$ in an interview. The expression refers to a mode of storytelling which is based on the fragmentation of the narrative into several parts, which are redistributed-here, between different Twitter handlesto finally create not only a story, but also a community. In the previously quoted interview, Cole calls such a community an "imagined community," 32 thus borrowing Benedict Anderson's phrase and correlating the act of writing to the act of communitybuilding, in a new non-linear form therefore able to capture the reader's attention. Such communities may be better understood in terms laid out by J. D. Bolter and R. Grusin as "mediated selves":

The remediated self is also evident in "virtual communities" on the Internet, in which individuals stake out and occupy verbal and visual points of view through textual and graphic manifestations, but at the same time constitute their collective identities as a network of affiliations among these mediated selves. The virtual community is the community as both subject and object of the process of remediation; it remediates the notion of community as defined in and through such earlier media as telegraph, telephone, radio, and television. ${ }^{33}$

13 Such "mediated selves," much like Judith Butler's recent conceptualization of assembly as a "new 'between' of bodies," 34 showcase the importance of sharing in the remediation process. Storytelling, in the few examples exposed above, appears to be 
intrinsically connected with communities, with the shared experience of the text. Attention is thus recaptured on several levels - the individual and the collective: from the latter to the former, a distinct space emerges. In the example of the Hooked platform, such an in-between space appears in the brief and serialized format of the stories, but also in their shared aspect-both in the collaborative aspect of the application, and in its heavy reliance on fanfiction.

\section{The experience of the text as a prerequisite} particular the experience of reading: the novelist argues that authors should make the reader operate within a specific reading mode. He connects this to his own vision of modernism and of the so-called "Gutenberg mind," as said previously. Such a conceptualization of reading as an experience as well as a process brings to mind the vision of reading as a reflexive act: it takes place thanks to a connection to the material aspect of the book, as opposed to supposedly dematerialized electronic books.

Publishing houses across the world have been paying close attention to the production of books as objects and thus laying a stronger emphasis on the distinction between the printed and electronic materials. Such a direction can be seen in mass market publishing houses as well as niche operations. For instance, Penguin launched a "Clothbound Classics" collection in 2008, thus rejuvenating world classics by publishing them as hardbacks with covers designed by a graphic artist, Coralie Bickford-Smith. Each book is bound in cloth, with a binary color scheme. Classical techniques like foil or embossing are used to borrow from the aspect of early twentieth-century books, while alluding to contemporary graphic design. For instance, the cover of Lewis Carroll's Alice in Wonderland is white with stylized pink flamingos, and Jane Austen's Sense and Sensibility is light blue, with red flowers. Such an editorial decision has proved commercially successful, and the collection has reinforced the place of such classics as both status symbols and decorative objects to be displayed. This example shows a renewed interest in reinforcing the specificity of the object as desirable and sensuous. This happens in opposition to a downloadable file insofar as the book implies a haptic experience which influences the reading process, a first physical contact with an object in which the reader accesses the experience of storytelling first through a reconciliation of optic sensations, touch, and smell. Books are treated like collectible items, status symbols and decorative objects, but also sensory objects stimulating several senses. Such an attentiveness to touch is present in the emphasis put on craft (for the Penguin "Clothbound" series, the feel of the slightly rough-woven fabric covering the book, as well as the embossed covers) and on the physical experience of reading (perusing the book in a bookstore, starting to read from elsewhere than the first page, folding pages, etc.). In an interview about her work for Penguin, BickfordSmith declares: "It's the tactile nature of a real book, the material feel of the grain of the cloth on the cover, the sense of encountering a greatly crafted object that people respond to." ${ }^{35}$ With this statement, Bickford-Smith underlines the importance of a human dimension to the book as object, seen as "crafted" rather than mass-produced: ebooks are presented as impersonal in this light. The reading experience therefore starts with a visual and haptic response to the book as an object, a first experience often related to the generalized pervasiveness of the adjective "real" in opposing 
ebooks and "real books," i.e. codices. In order to foreground this perceived materiality, all the aspects of the book as object might be fetishized, from the experience of turning the page, reproduced by software for electronic reading devices, to the sense of smell with the production of perfumes intended to reproduce the scent of books, or the creation of bespoke fragrances (inspired by the atmosphere of books or bookstores). For instance, the Parisian bookstore Shakespeare and Company proposes to customize online book orders by stamping the books and perfuming them with a scent meant to evoke the atmosphere of the bookshop. Olfactory marketing is therefore used to complement the work on the haptic aspect of books.

Such evolutions are also marked by a growing interest in reading as a reflexive act: reading, in the age of electronic literature, is specific in its relationship to the material. As we have seen above, in a development of collections meant to produce desirable objects, publishers develop means of garnering the reader's attention by introducing playfulness to the reading process. For instance the London-based publishing house Visual Editions issued a new edition of Tristram Shandy in 2010-an edition meant, according to the press release, to give the text its original "magic." The 2010 Tristram Shandy thus plays with colors inside the text so as to bring to the fore the metatextual and playful elements of Sterne's work. For instance, dashes are printed in red (it is the dominant color of the book), like some originally hand-drawn signals or large letters inlaid in the background of a page. ${ }^{36}$ The texture of pages is also modified, with glossy, transparent spots added to some pages. Such playfulness was also found in the commercial success of the novel S., written by Doug Dorst and designed by film director J. J. Abrams in 2013; in the novel, the reader is meant to complement his or her reading experience with objects added to the book (postcards, letters, a cardboard compass), and to take into account the false marginalia present in the book, itself presented as an old library book scribbled over by several characters. Such a playful approach to storytelling, reminiscent of Jonathan Safran Foer's 2010 Tree of Codes, involves an articulation of the editorial and the writing processes, and borrows from the experimentations of movements like the French OuLiPo while targeting a much wider audience. Storytelling is approached as an essentially experiential process: in order to capture the reader's attention, books-both printed and digital-are thought as devices meant to be experienced.

\section{Convergence, experience, and space}

Reading as a contemporary and evolving process takes place as a shared synchronic experience, close to what Henry Jenkins calls "communal [...] modes of reception." ${ }^{37}$ Its occurrence is precisely based on the convergence of experience, time, and space. Such a convergence is often based on social media; readers may share their experience through a number of outlets which can be general like Reddit (in specific subgroups) or Twitter, or specific to books like the website Goodreads. One may even consider the public notes on Amazon's Kindle ebooks ${ }^{38}$ to be a form of feedback and exchange for readers. A large part of the inclusion of the reading experience within "convergence culture" 39 is based on such a creation of communities through the virtual encounters of readers, in a modus operandi which is close to that of the older fandoms. While particularly visible for genre fiction, the digital convergence of readers is now a 
common occurrence, for instance as evidenced in Mark Z. Danielewski's 2000 novel House of Leaves.

The convergence also operates on the level of writing. Here we may envision an evolution to Robert Darnton's fundamental 1982 book production scheme, ${ }^{40}$ which takes into account all those involved in the production of books. In an updated, contemporary version, one may need to add a loop including authors who take readers into account while writing (and this outside of the serial format). Authors frequently ask for feedback, or even use reader suggestions as prompts for stories. This is for instance a strategy used by British author Neil Gaiman in 2014. Gaiman wrote the novella "A Calendar of Tales" as a collaborative experiment which lasted for twelve hours. Every hour, the author would post a writing prompt, like "If August could speak, what would it say?," on his official Twitter account. Gaiman's readers were asked to post their textual and visual reactions to the prompts. The resulting ideas were then used by the novelist as a basis for the novella, published in the collection Trigger Warning. The initiative was partly funded by the technology company Blackberry, and even though the resulting narrative was not intermedial, the involvement of such a company should be foregrounded since the very nature of the Blackberry company serves to showcase the importance of new technologies (and the corporations producing them) in some contemporary writing practices. It should be noted here that the growing importance of tech companies in the writing and publishing processes only strengthens the need to pay attention to material and economic concerns in the book industry, as traditional publishing patterns evolve. "A Calendar of Tales" was indeed initiated by Blackberry, but the final product-the collection of short stories-was published by Headline. The intervention of a patron is by no means new in publishing; this particular case serves as a textbook example of the integration of tech companies in publishing. It should also be noted that the project website is no longer accessible: all that remain are Youtube videos of the project; this should be noted as archiving such projects is a crucial question dictated by the way data is currently stored in data centers, and by the cost of such maintenance.

Other instances of new actors in the writing process are distinct since they are not connected to the avant-garde but rather to external concerns. For instance, authors may, for charity, add a donor's likeness or name in a novel-a practice often found in annual fundraisers like the American charity Worldbuilders, which involves authors and publishers, with both parties providing gifts for donors. Authorship thus becomes closer to readership, especially in the case of genre fiction. Some authors even inform their readers of the progress of a manuscript thanks to bars on their website-this is a common practice in genre fiction. For instance, the American fantasy author Brandon Sanderson frequently provides updates to his readers on his website, distinguishing the stages of writing from first draft to the early release of the manuscript to his beta readers. These new practices participate in the consolidation of a community, but they also short-circuit the older production schemes, and texts exist in a way that is subject to a profound structural change in their production and their reception.

The convergence at work in storytelling emerges not only in the writing process, but also in the reception of transmedia apparatuses, and the way literature can be staged. Experiments in storytelling as a transmedia enterprise have been created recently, especially as a reaction to the constant transformations of the book and of the general reading experience, notably with the possibilities offered by electronic books, like 
reading non-linearly, with search terms. E-readers are indeed sometimes used by readers not to access texts in the intended manner, but to look for specific keywords by using the search engine embedded in the device. Texts are then accessed through an individualized index. One such experiment explored storytelling as an experience, in a museum: the 2013 "Memory Palace" exhibition held at the Victoria and Albert Museum in London, which was curated by Laurie Britton Newell and Ligaya Salazar. The exhibition was conceived as a "physically immersive illustrated story that explores the idea of an exhibition as a walk-in book"41 (Britton Newell and Salazar). The two curators were prompted in their endeavor by a comment written by their American colleague Andrew Blauvelt: "in the future, most designers will be creating reading experiences not book designs." ${ }^{42}$ Their first focus was therefore the increasingly complex poetics of storytelling, and the inclusion of the experience in the act of reading. They commissioned a short story from British author Hari Kunzru, and once the text was written, several artists (illustrators, typographers, graphic designers) to create a visual journey through the story. The suggested trajectory was only present on handouts given to the visitors, who could then decide to experience the story in a nonlinear manner. Kunzru wrote the short story "Memory Palace" by using the principle of the exhibition, the manipulation of memory. The story is set in a dystopian future and borrows from tropes of the science-fiction genre. The title is based on the Italian sixteenth-century philosopher Giordano Bruno, who in his 1583 Ars reminiscendi developed mnemonic techniques based in part on the visualization of a "memory palace." Kunzru envisions the consequences of an electrical storm which has destroyed all the digital infrastructures of the world. The world has fallen into a "dark age" called the "Withering," where the transmission of memories is forbidden-the narrator is a member of a tribe defending the art of memory, the "Memorialists," and who is arrested for having formed an illegal gathering, ironically called an "internet." His memories create the stories, the "memory palace" the visitors can walk through. The illustrations include installations, videos, sculptures and traditional illustrations, as a nod to the nature of the Victoria and Albert Museum and to the themes of the short story. For instance, illustrator Jim Kay ${ }^{43}$ produced what looked like a medieval portable reliquary cabinet meant to illustrate the "Law of Milord Darwin," featuring elements of Darwin's Origin of Species which are forbidden in Kunzru's dystopia. The cabinet contains a delicate sculpted tree, and a crow, perched on top of the open doors, with a twig in its beak. The two sides of the reliquary are richly painted in the medieval manner, and accented in gold paint, the better to combine violent scenes containing contemporary objects, and medieval imagery and composition. Behind Kay's work, Kunzru's text is writ large; Kay illustrated the main character's final confession in prison, thus connecting medieval religious art and the motif of the confession as a religious element, as well as some of the objects displayed in the permanent collections of the museum. The curators engaged in the creation of a multimedia experience, one where the reading experience is connected with physical progress within a set space. Their spatialization of the text is meant as an echo to the literal process of memorialization of the narrator, a translation of the metaphor of the palace. Johnny Kelly, an artist specializing in graphic design and animation, created an interactive installation to mark the end of the story, where the visitors could write on a tablet (each entry being labeled a "memory"), thereby creating a work of art and memory bank which was printed once a week and then integrated to the exhibition. Such choices enabled the curators to question the evolving nature of storytelling as an 
experiential process, one that could be conducted in a linear fashion and through free association, and as a written text or as a physical experience.

21 Storytelling as a physical process bears on the parallel between reading and walking, once again leading us to consider the embodiment of literature and its inclusion in a shared, communal space acting as an interface between readers and the texts (another facet to Butler's “'between' of bodies," ${ }^{44}$ perhaps): the construction of narrative through the use of space is present in popular genres as well as experimental literary forms. Be it in the contemporary revival of nature writing in Great Britain (spearheaded by popular authors like Helen MacDonald or Robert MacFarlane) or in the increasingly frequent publication of location-aware narratives, space is taken into account in the reading process more than ever. For instance, the University of Southampton established the "StoryPlaces Project," 45 an urban exploration as much as it is a literary project. Through a smartphone application, readers may access short stories thanks to their exploration of the city. The application uses the phone's GPS to unlock stories written by local authors. In this case, there is no codex, the storytelling process is articulated around "nodes" and each story is built around several such nodes. The reading process is not necessarily linear (but the stories are), operating instead like a hyperlinked text. The University recently opened an "authoring tool," in which visitors can contribute their own stories, choosing or not to make them public. The process, inspired by experimental works like Raymond Queneau's 1961 combinatory text Hundred Thousand Billion Poems, focuses on the impact of new technologies on reading and writing, but also on the poetics of space. Indeed, such projects-still mostly confined to the experimental, niche domain, explore the interaction between readers inhabiting the space of a text (its immersive qualities) and readers inhabiting the physical space of the city. In this particular context, the reading communities may inhabit the very same space, with the text as an interface, and an embodiment that becomes even more layered than originally envisioned.

A similar process is used with works which use specific locations, but without requiring the reader's spatial involvement-such a take on location-aware narratives is easier to implement since it does not require for the author or the publisher to take into account notions of distance, time, or safety, both physical and digital. For example, the American author Reif Larsen wrote Entrances \& Exits, an ebook published by Visual Editions in 2016. The story is meant to be read on a smartphone or a tablet, as it is structured by Google Street View: the reader discovers a key in an abandoned bookstore, which will open and close virtual doors all over the world. In this case, as the publishing house underlines in its digital presentation of the text, the narration remains linear, the reader has no choice of "nodes," and is active insofar as the preestablished story is followed. Unlike the combinatory, interactive texts based on a hyperlink structure, Entrances \& Exits's use of space and virtuality favors a reading experience which is both similar to the experience of reading a linear narrative, and distinct since the reader becomes a participant in the story.

Storytelling takes place, in this context, as a temporal and spatial occurrence; this leads us to consider it as dominated by the notion of convergence. In the creation of works like the "Memory Palace" exhibition or Gaiman's "A Calendar of Tales," the apparent duality opposing the material book and its disembodied counterpart is challenged. While more and more printed books try to engage us in new modes of reading related to the influence of digital literature, we have seen that digital books borrow from the 
aspect of their printed counterparts as well. One should also remember that the designation "disembodied," or "immaterial" should be nuanced since the very existence of digital files is predicated on a significant quantity of hardware (computers, servers, internet cables, satellites, etc.). We therefore propose to consider the evolution of storytelling in contemporary literature as a phenomenon based on convergence. In Jenkins' analysis of what he calls "convergence culture," 46 the key to contemporary culture is shown to be the encounter of different media spheres, and modes of expressions. We would like to argue that this could be expanded to a consideration of storytelling as partly dependent on transmedia and on the growing presence of different media seen as tools to create narratives. These narratives would then not necessarily exclusively be accessed through different media, but rather borrow from different access strategies. Indeed, storytelling occurs via different mediums often perceived as competing, when they are joined by a transmedia convergence.

Seeing storytelling in the digital age within this framework may bring about a friction, a point of contact between several mediums that creates specific, new effects (I borrow this use of the term friction from Lori Emerson ${ }^{47}$ ). "A Calendar of Tales," for instance, may be read not exclusively as a short story composed of shorter stories (as an uninformed reader may read it in the anthology Trigger Warning), but also as a story with an embedded narrative-that of the writing prompts provided by Neil Gaiman's Twitter followers. Storytelling, although it is increasingly challenged according to some, appears through the convergence of material and transmedia occurrences, which is now a well-documented element. Such a text also brings about the question of how storytelling is constructed by-and constructs-its own access. Here, the reading experience will differ according to the previous information provided to the reader. A version of the short story was first accessible in a PDF document on Gaiman's American editor's website, Tor. The later inclusion of the story within the collection Trigger Warning led the author to include a short explanation in the introduction. In this introduction, Gaiman explains that the project is based first on his fascination for Harlan Ellison, who "demonstrat[ed] to the world that writing was a craft, that it was not an act of magic." ${ }^{48}$ The project was then prompted by the aforementioned collaboration with Blackberry, meaning that the stories written by Gaiman were in turn used as prompts for visual art by his followers. In such a context, the act of storytelling means a dual access to the text, showing that the friction we have observed is rooted in issues of attention and materiality.

In fine, storytelling in contemporary literature intersects with the variations in its publication, especially regarding electronic literature and, far from disappearing, appears to have taken center stage again. In the end, Self's declarations about the novel need to be re-evaluated, as he described the literary novel as an "undead art form that yet wouldn't lie down." ${ }^{49}$ The emerging practices, due to the multiplication of reading formats, are then hybrid as they combine several modes of reading, of writing, of conceiving the act of reading as something connected to a community. 


\section{BIBLIOGRAPHY}

Anderson, Benedict. Imagined Communities: Reflections on the Origin and Spread of Nationalism. London: Verso, [1983] 1991.

Benjamin, Walter. "The Work of Art in the Age of Mechanical Reproduction.” Translated by Harry Zohn. In Illuminations, Essays and Reflections, edited by Hannah Arendt, 217-52. New York: Schocken Books, 2007.

Birkerts, Sven. The Gutenberg Elegies: The Fate of reading in an Electronic Age, New York: Farrar, Straus and Giroux, 1994.

Blauvelt, Andrew. "From Books to Texts." In I Read Where I Am: Exploring New Information Cultures, edited by Mieke Gerritzen, Geert Lovink and Minke Kampman. Amsterdam: Valiz, 2011, 53-4.

Bolter, Jay David and Richard Grusin. Remediation, Understanding New Media. Cambridge [Mass.]: MIT Press, 2000.

Britton Newell, Laurie and Ligaya Salazar. "Making Memory Palace." Accessed February 04, 2020. http://www.vam.ac.uk/content/exhibitions/exhibition-sky-arts-ignition-memory-palace/ making-memory-palace/

Butler, Judith. Notes Toward a Performative Theory of Assembly. Cambridge [Mass.]: Harvard University Press, 2015.

Cameron, Lauren. "Marginalia and Community in the Age of the Kindle: Popular Highlights in "The Adventures of Sherlock Holmes"." Victorian Review 38, no. 2 (2012): 81-99. Accessed October 12, 2020. http://www.jstor.org/stable/23646685.

Chow, Rey. Entanglements, or Transmedial Thinking About Capture. Durham [NC]: Duke University Press, 2012.

Cole, Teju (@tejucole). “Hafiz”, Twitter thread, 8, January 2014. https://twitter.com/tejucole/ timelines/437242785591078912

Crary, Jonathan. Suspensions of Perception. Attention, Spectacle and Modern Culture. Cambridge [Mass.]: MIT Press, [1999] 2001.

Darnton, Robert. "What Is the History of Books?" Daedalus 111, no. 3 (1982): 65-83. Accessed February 4, 2020. http://www.jstor.org/stable/20024803.

Emerson, Lori. Reading Writing Interfaces: From the Digital to the Bookbound. Minneapolis: The University of Minnesota Press, 2014.

Foster, Hal, The Art-Architecture Complex. London, New York: Verso. 2011.

Gaiman, Neil. Trigger Warning. London: Headline, 2015.

Galloway, Alexander R. “The Unworkable Interface.” New Literary History 39, no. 4 (2008): 931-955. doi:10.1353/nlh.0.0062.

Goggin, Gerard. Cell Phone Culture: Mobile Technology in Everyday Life. London: Routledge, 2006.

Hayles, N. Katherine. Electronic literature: New horizons for the literary. Notre Dame [IN]: University of Notre Dame Press, 2008.

HOOKED-Chat Stories. “Advertisement”. Accessed February 4, 2020, https://itunes.apple.com/us/ app/hooked-chat-stories/id1024818709?mt=8. 
Jenkins, Henry. Convergence Culture: Where Old and New Media Collide. New York: New York University Press, 2006.

Katayama, Lisa. “Big Books Hit Japan's Tiny Phones,” Wired (2007), accessed December 16, 2020, https://www.wired.com/2007/01/big-books-hit-japans-tiny-phones/

LaForce, Thessaly, “The Boundary-Pushing Novelist Who's Made Twitter His new Medium.” Wired. Last Modified July 22, 2014. Accessed February 4, 2020. https://www.wired.com/2014/07/ teju-cole-twitter/.

McLuhan, Marshall. The Gutenberg Galaxy: The Making Of Typographic Man. Toronto: University of Toronto Press, [1962] 2010.

Metz, Bernhard. "Readable Text, Unreadable E-Texts? How Digital Reading and Writing Devices Changed Literary Texts and Reading Habits". In Book Practices \& Textual Itineraries: Textual Practices in the Digital Age, edited by Nathalie Collé-Bak, Monica Latham and David Ten Eyck, 17-47. Nancy: Presses Universitaires de Lorraine, 2014.

Page, Ruth and Bronwen Thomas, eds. New Narratives: Stories and Storytelling in the Digital Age, Lincoln: University of Nebraska Press, 2011.

Pessl, Marisha. Night Film. New York: Random House, 2013. Kindle.

Ryan, Marie-Laure. “Transmedial Storytelling and Transfictionality.” Poetics Today 34, no. 3 (Fall 2013): 361-88.

"Le transmedia storytelling comme pratique narrative." Revue française des sciences de l'information et de la communication 10 (2017). https://doi.org/10.4000/rfsic.254.

Self, Will. "The Novel Is Dead (This Time It's For Real)." The Guardian Online. Last modified May 2, 2014. Accessed February 4, 2020. https://www.theguardian.com/books/2014/may/02/will-selfnovel-dead-literary-fiction.

“Are Humans Evolving Beyond the Need to Tell Stories?". The Guardian Online. Last modified November 25, 2016. Accessed February 4, 2020. https://www.theguardian.com/books/ 2016/nov/25/will-self-humans-evolving-need-stories.

von Hahn, Karen. “Designer's Classic Jackets a Boon for Bookstores.” The Toronto Star Online. Last modified December 19, 2015. Accessed February 4, 2020. https://www.thestar.com/life/ 2015/12/19/designers-classic-jackets-a-boon-for-bookstores.html

Wired. "Big Books Hit Japan's Tiny Phones." Wired. Last modified January 3, 2007. Accessed February 4, 2020. https://www.wired.com/2007/01/big-books-hit-japans-tiny-phones/.

\section{NOTES}

1. Will Self, “The Novel Is Dead (This Time It's For Real)”, The Guardian Online, last modified May 2, 2014, accessed February 4, 2020, https://www.theguardian.com/books/2014/may/02/will-selfnovel-dead-literary-fiction.

2. On the topic, see Marshall McLuhan's The Gutenberg Galaxy: The Making Of Typographic Man (1962, Toronto: University of Toronto Press, 2010) or Sven Birkerts's The Gutenberg Elegies: The Fate of reading in an Electronic Age (1994, New York: Farrar, Straus and Giroux).

3. Self, "The Novel is Dead."

4. McLuhan, The Gutenberg Galaxy, 166.

5. Self, "The Novel is Dead." 
6. Will Self, "Are Humans Evolving Beyond the Need to Tell Stories?", The Guardian Online, Last modified November 25, 2016, accessed February 4, 2020, https://www.theguardian.com/books/ 2016/nov/25/will-self-humans-evolving-need-stories.

7. Self, "Are Humans Evolving Beyond the Need to Tell Stories?"

8. In this respect, Self disregards recent scientific research in the field of cognitive neurosciences regarding reading processes, as well as the debates sparked by the study of the way we process the written word.

9. N. Katherine Hayles. Electronic literature: New Horizons for the Literary (Notre Dame [IN]: University of Notre Dame Press, 2008), 3.

10. I am using the term "electronic literature" in this paper as a means to refer to literature produced for the digital medium and not digitized printed material-this follows N. Katherine Hayle's definitions in "Electronic Literature: What is it?" (See N. Katherine Hayles, "Electronic Literature: What is it?", The Electronic Literature Association, January 2, 2007, accessed October 12, 2020, https://eliterature.org/pad/elp.html\#sec1)

11. Jay David Bolter and Richard Grusin, Remediation, Understanding New Media (Cambridge [Mass.]: MIT Press, 2000).

12. Marisha Pessl, Night Film (New York: Random House, 2013. Kindle).

13. Ibid.

14. Alexander Galloway, "The Unworkable Interface," New Literary History 39, no. 4 (Autumn 2008): 936.

15. Henry Jenkins, Convergence Culture: Where Old and New Media Collide (New York: New York University Press, 2006), 21.

16. See Marie-Laure Ryan, "Transmedial Storytelling and Transfictionality," Poetics Today 34, no. 3 (Fall 2013): 363.

17. Henry Jenkins, Convergence Culture: Where Old and New Media Collide (New York: New York UP, 2006): 21.

18. Hayles, Electronic literature, 163.

19. See Marie-Laure Ryan, "Le transmedia storytelling comme pratique narrative," Revue française des sciences de l'information et de la communication 10 (2017), accessed February 4, 2020 http://rfsic.revues.org/2548.

20. See in particular Marie-Laure Ryan, "The Interactive Onion," in Ruth Page and Thomas Bronwen, eds., New Narratives: Stories and Storytelling in the Digital Age (Lincoln: University of Nebraska Press, 2011): 35-62.

21. It should however be noted that the switch to a digital format, for novels, means more formal linearity, with the suppression of line and page breaks, for instance. See Bernhard Metz,"Readable Text, Unreadable E-Texts? How Digital Reading and Writing Devices Changed Literary Texts and Reading Habits," in Book Practices \& Textual Itineraries: Textual Practices in the Digital Age, eds. Nathalie Collé-Bak, Monica Latham and David Ten Eyck (Nancy: Presses Universitaires de Lorraine, 2014): 20-1.

22. On the topic, see Henry Jenkins, Convergence Culture and Marie-Laure Ryan, "Le transmedia storytelling comme pratique narrative."

23. Walter Benjamin, "The Work of Art in the Age of Mechanical Reproduction," trans. Harry Zohn, in Illuminations, Essays and Reflections, ed. Hannah Arendt (New York: Schocken Books, 2007).

24. Benjamin, "The Work of Art", 240.

25. Ibid., 241.

26. Jonathan Crary, Suspensions of Perception. Attention, Spectacle and Modern Culture (1999, Cambridge [Mass.]: The MIT Press, 2001), 3, original emphasis.

27. See Katayama, "Big Books Hit Japan's Tiny Phones," and Gerard Goggin, Cell Phone Culture: Mobile Technology in Everyday Life (London: Routledge, 2006). 
28. See "The Cell Phone Novel Network (@CellPhoneNovel) - Wattpad."

29. HOOKED-Chat Stories. Accessed February 4, 2020, https://itunes.apple.com/us/app/hookedchat-stories/id1024818709? $\mathrm{mt}=8$.

30. HOOKED-Chat Stories.

31. Thessaly LaForce, "The Boundary-Pushing Novelist Who's Made Twitter His New Medium," Wired 22 (July 2014), accessed February 04, 2020, https://www.wired.com/2014/07/teju-coletwitter/.

32. Benedict Anderson, Imagined Communities: Reflections on the Origin and Spread of Nationalism (1983. London: Verso, 1991), 7.

33. Jay David Bolter and Richard Grusin, Remediation, 232-3.

34. Judith Butler, Notes Toward a Performative Theory of Assembly (Cambridge [Mass.]: Harvard University Press, 2015), 85.

35. Karen von Hahn, "Designer's Classic Jackets a Boon for Bookstores," The Toronto Star Online, last modified December 19, 2015), accessed February 4, 2020, https://www.thestar.com/life/ 2015/12/19/designers-classic-jackets-a-boon-for-bookstores.html.

36. The edition is currently out of print, but photographs of the book may be seen on the publishing company's companion website, accessed February 4, 2020 http://2005.visualeditions.com/our-books/tristram-shandy.

37. Jenkins, Convergence Culture, 26.

38. On this electronic reading device, the reader may add notes while reading, and may display these notes publicly or keep them private. Such a phenomenon is currently being investigated as a contemporary equivalent to medieval marginalia. See L. Cameron's case study of Amazon's "popular highlights" feature for The Adventures of Sherlock Holmes as marginalia influencing the way readers access the digital text. Lauren Cameron, "Marginalia and Community in the Age of the Kindle: Popular Highlights in 'The Adventures of Sherlock Holmes', Victorian Review 38, no. 2 (2012): 81-99.

39. Jenkins, Convergence Culture, 20.

40. Robert Darnton, “What is the History of Books?" Daedalus 111, no. 3 (Summer 1982): 68.

41. Laurie Britton Newell and Ligaya Salazar, "Making Memory Palace," Victoria and Albert Museum Website, accessed February 4, 2020, http://www.vam.ac.uk/content/exhibitions/ exhibition-sky-arts-ignition-memory-palace/making-memory-palace/.

42. Andrew Blauvelt,"From Books to Texts," in I Read Where I Am: Exploring New Information Cultures, eds. Mieke Gerritzen, Geert Lovink and Minke Kampman (Amsterdam: Valiz, 2011), 53.

43. Jim Kay is an acclaimed illustrator of children's books, and graphic novels.

44. Butler, Notes Toward a Performative Theory of Assembly, 85.

45. University of Southampton, accessed February 04, 2020, http://storyplaces.soton.ac.uk.

46. Jenkins, Convergence Culture, 20.

47. Lori Emerson, Reading Writing Interfaces: From the Digital to the Bookbound (Minneapolis: The University of Minnesota Press, 2014), xii.

48. Neil Gaiman, Trigger Warning (London: Headline, 2015), xxiii.

49. Self, "The Novel is Dead." 


\section{ABSTRACTS}

This article, stemming from research in contemporary book studies and new media studies aims at showing the recent evolutions of storytelling practices in contemporary literature, more specifically in their relationship with electronic forms of literature. Starting with the recent resurgence of the "death of the novel" trope, we attempt to map out the way elements of contemporary literature have in part evaded the perceived opposition between print and electronic literature, to build a new form of storytelling which is characteristic in its construction of a specific way of reading. Since it has been established that reading practices are influenced by the evolution of reading devices, storytelling is in turn informed by these evolutions. Electronic literature as such has been studied extensively, as well as its direct aesthetic influence on avant-garde works like Mark Z. Danielewski's House of Leaves. This influence has reached different audiences and may be connected to other productions referred to under Henry Jenkins' umbrella term "transmedia storytelling." Then, forms of contemporary storytelling have attempted to regain the reader's fractured attention, notably through the manipulation of experience and immersion in time and space -geolocalised narratives, stories told through social media, or lived stories translated into a museum. Storytelling is thus informed not only by its source, but by a great variety of variables like touch, smell, or spatial experience, to regain a sense of connectedness in the act of telling stories. In seeing storytelling as a synchronic experience, we then focus on works both targeting a specific audience used to experimental texts or productions, or niche audiences expecting genre fiction.

\section{INDEX}

Keywords: electronic literature, digital literature, transmedia storytelling, immersion, reception

\section{AUTHOR}

\section{CÉCILE BEAUFILS}

Cécile Beaufils is Senior Lecturer in Contemporary British Literature at Sorbonne Université, where she teaches British literature, visual studies and critical theory in the English Department. Her research focuses on contemporary literature seen through the lens of book studies and cultural studies. She has published peer-reviewed papers on the literary magazine Granta as a cultural phenomenon ("Disembodied Texts, Online Materiality: The Case of Granta." Book Practices \& Textual Itineraries 2: Textual Practices in the Digital Age, 2014), and on the recent evolutions of publishing in Britain in their aesthetics and impact ("Nature Writing and Publishing: The Ethics of a Cultural Mapping," Études britanniques contemporaines, 2018). Her current projects involve a study of nature writing in contemporary publishing.

Sorbonne Université cecile.beaufils@sorbonne-universite.fr 